\title{
Attenuated liver fibrosis in the absence of $B$ cells
}

\author{
Tatiana I. Novobrantseva, ${ }^{1}$ Gerard R. Majeau, ${ }^{1}$ Aldo Amatucci, ${ }^{1}$ Sophia Kogan, ${ }^{1}$ Ian Brenner, ${ }^{1}$ \\ Stefano Casola, ${ }^{2}$ Mark J. Shlomchik, ${ }^{3}$ Victor Koteliansky, ${ }^{1}$ Paula S. Hochman, ${ }^{1}$ \\ and Alexander Ibraghimov ${ }^{1}$
}

\begin{abstract}
${ }^{1}$ Immunology Department, Biogen Idec, Cambridge, Massachusetts, USA. ${ }^{2}$ The CBR Institute for Biomedical Research, Harvard Medical School, Boston, Massachusetts, USA. ${ }^{3}$ Department of Laboratory Medicine and Section of Immunobiology, Yale University School of Medicine, New Haven, Connecticut, USA.
\end{abstract}

\begin{abstract}
Analysis of mononuclear cells in the adult mouse liver revealed that $B$ cells represent as much as half of the intrahepatic lymphocyte population. Intrahepatic B cells (IHB cells) are phenotypically similar to splenic B2 cells but express lower levels of CD23 and CD21 and higher levels of CD5. IHB cells proliferate as well as splenic $B$ cells in response to anti-IgM and LPS stimulation in vitro. VDJ gene rearrangements in IHB cells contain insertions of $N, P$ region nucleotides characteristic of $B$ cells maturing in the adult bone marrow rather than in the fetal liver. To evaluate whether $\mathrm{B}$ cells can have an impact on liver pathology, we compared $\mathrm{CCl}_{4}$-induced fibrosis development in $\mathrm{B}$ cell-deficient and wild-type mice. $\mathrm{CCl}_{4}$ caused similar acute liver injury in mutant and wild-type mice. However, following 6 weeks of $\mathrm{CCl}_{4}$ treatment, histochemical analyses showed markedly reduced collagen deposition in $B$ cell-deficient as compared with wild-type mice. By analyzing mice that have normal numbers of $B$ cells but lack either $T$ cells or immunoglobulin in the serum, we established that $B$ cells have an impact on fibrosis in an antibody- and $\mathrm{T}$ cell-independent manner.
\end{abstract}

\section{Introduction}

The functions of the liver, such as removal of pathogens and antigens from the blood, protein synthesis, and metabolism, require an immune response that is adapted to these tasks and is locally regulated. The liver is rich in immune cells. In addition to the presence of large numbers of resident macrophages (Kupffer cells), the liver contains T cells, NK cells, and NKT cells $(1,2)$. Interestingly, no mention of B cells in the adult mouse liver is found in most reviews, even though embryonic liver is a well-studied site of origin for B cells and B lymphopoiesis persists in liver for 2 weeks after birth (3). B cells originating from the embryonic liver have the phenotype of $\mathrm{B} 1$ cells $\left(\mathrm{CD}^{+}, \mathrm{CD}_{4} 3^{+}, \mathrm{Mac}-1^{+}\right)$, encode a particular set of $B$ cell receptor specificities, reside mostly in the peritoneal cavity (PC) and the pleural cavity, and carry little, if any, $\mathrm{N}$ nucleotide insertions in their VDJ joints (4). All these features are distinctly different in $\mathrm{B} 2$ cells, the predominant population of $\mathrm{B}$ cells in the adult mouse (4).

Since little is known about B cells in the adult liver, we decided to look for adult mouse hepatic B cells and, if they were found, to characterize them phenotypically and with respect to their possible involvement in the response to liver injury. We chose the carbon tetrachloride-induced $\left(\mathrm{CCl}_{4}\right.$-induced) liver degeneration model of liver disease to avoid targeted activation of a specific subset of lymphocytes a priori, as LPS or concanavalin A-induced liver damage stimulates B cells/macrophages or T cells, respectively $(5,6)$. The hallmarks of chronic liver diseases, such as alcohol-induced liver degeneration, hepatitis $\mathrm{C}$ infection, and nonalcohol-induced steatohepatitis, are chronic inflammation, cellular

Nonstandard abbreviations used: ALT, alanine aminotransferase; ANIT, $\alpha$-naphthylisothiocyanate; $\mathrm{BAFF}, \mathrm{B}$ cell activating factor; $\mathrm{CCl}_{4}$, carbon tetrachloride; colI, collagen I; DAB, 3,3'-diaminobenzidine; IH, intrahepatic; IHB, IH B (cell); PC, peritoneal cavity.

Conflict of interest: The authors have declared that no conflict of interest exists.

Citation for this article: J. Clin. Invest. 115:3072-3082 (2005).

doi:10.1172/JCI24798. damage, regeneration, and fibrosis. All of these features can be evoked by repeated $\mathrm{CCl}_{4}$-induced liver injury.

The hepatotoxicity of $\mathrm{CCl}_{4}$ is thought to involve 2 phases. First, $\mathrm{CCl}_{4}$ is metabolized by cytochrome P450 (expressed at high levels in centrilobular hepatocytes; ref. 7) to produce trichloromethyl radicals, which cause lipid peroxidation and membrane damage. The second phase is an inflammatory response launched by resident hepatic macrophages, the Kupffer cells, which upon activation, secrete cytokines, chemokines, and other proinflammatory factors (IL-18, TNF- $\alpha$, IL-1, IL-6, IL-8, eicosanoids, and NO). In addition to having direct cytotoxic effects, these factors attract and activate other monocytes as well as neutrophils and lymphocytes, which all contribute to tissue damage. Initial damage is followed by a phase of repair that includes a TGF- $\beta$-induced increase in collagen I (colI) production (8). Repeated cycles of injury, inflammation, and repair result in fibrosis. Accumulation of coll occurs in the space between hepatocytes and endothelial cells, where it replaces a low-density basement membrane-like matrix containing colIV. This conversion of the subendothelial matrix to a matrix rich in fibrillar coll is a pivotal event mediating the loss of differentiated functions characteristic of progressive liver disease.

In an alternative model, liver injury is induced by biliary toxin $\alpha$-naphthylisothiocyanate (ANIT), mimicking biliary cirrhosis and sclerosing cholangitis (9). ANIT, similarly to $\mathrm{CCl}_{4}$, induces nonimmune cell-targeted hepatotoxicity followed by inflammatory and fibrotic responses, although at a different hepatic anatomic location compared with $\mathrm{CCl}_{4}$.

Here we characterize intrahepatic B (IHB) cells with respect to cell phenotype, $\mathrm{N}$ nucleotide insertions at the VDJ junction, and their functional properties as well as describe a critical role for $\mathrm{B}$ cells in fibrotic liver disease models.

\section{Results}

$B$ cells represent a major lymphocyte population in the liver. B cells have been extensively studied in embryonic liver, the major site of 
A
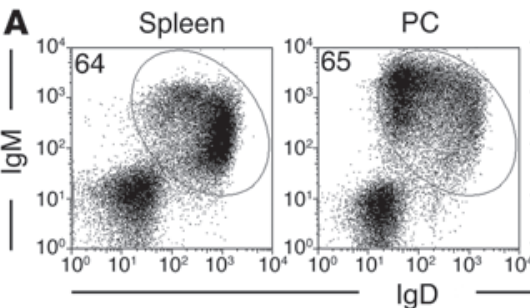

B
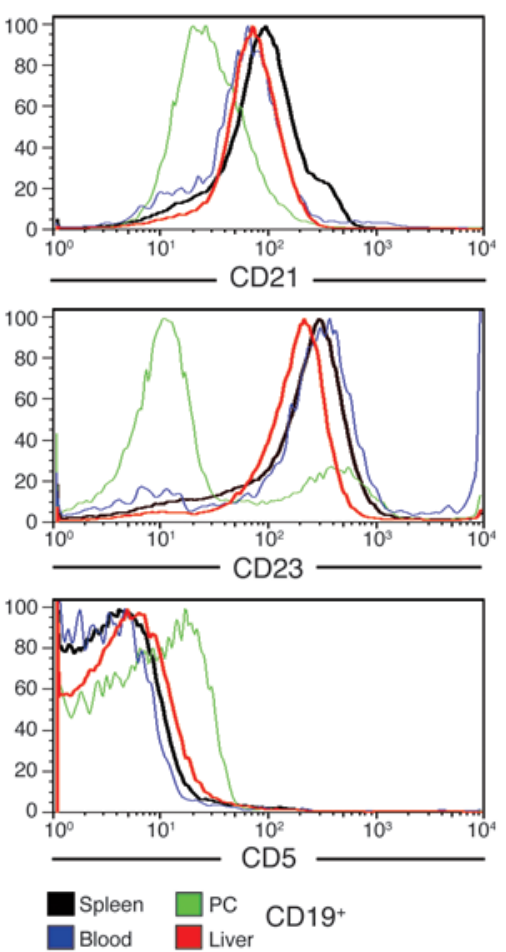

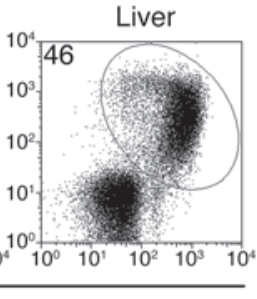

C

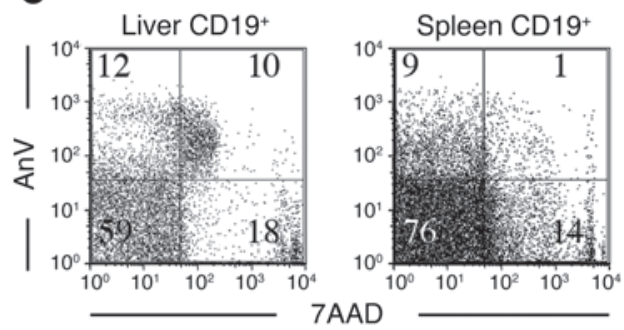

D

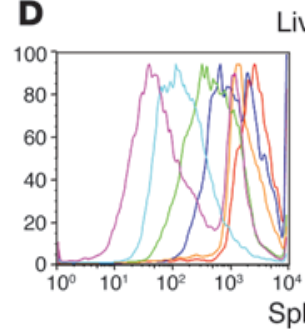

Liver

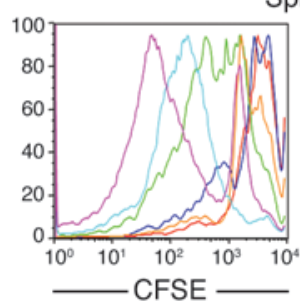
leen

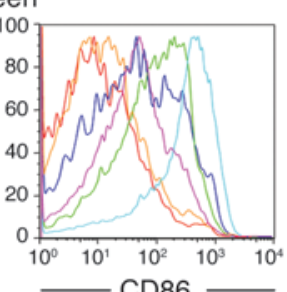

\section{Figure 1}

Phenotypic and functional characterization of IHB cells. (A) Lymphocytes defined by their scatter (51) were stained with anti-lgD ( $x$ axis) and anti-IgM ( $y$ axis). Percentages of $\operatorname{lgM}^{+}$and $\operatorname{lgD}^{+}$cells are shown next to the gate. (B) The histograms compare the levels of CD21, CD23, and CD5 on CD19+ B cells from spleen, blood, $P C$, and liver. (C) Viability of CD19+ $\mathrm{B}$ cells from liver and spleen was assessed by staining with the DNA intercalating reagent 7AAD and annexin $V$ $(\mathrm{AnV})$; double-negative cells are viable. (D) Residual CFSE fluorescence intensity and CD86 levels in CFSE-labeled B cells from liver (upper panels) and spleen (lower panels) after 3.5 days of activation in the presence of different stimuli noted. NS, no stimulation. hematopoiesis in the developing embryo. However, little is known about hepatic B cells in the adult liver. We set out to phenotypically and functionally characterize IHB cells.

We quantified the proportion of IHB cells in a lymphocyteenriched population from PBS-perfused liver by staining for CD19, a B lineage-specific marker. In both BALB/c and C57BL/ 6 mice, B cells represent about $50 \%$ of intrahepatic (IH) lymphocytes (range 30-60\%; Figure 1A and data not shown). The absolute number of $B$ cells isolated from a liver was approximately $2 \times 10^{6}$. CD $19^{+} \mathrm{IHB}$ cells were shown to express IgM, IgD, B220, MHCII, and CD62L at levels similar to their splenic counterparts (Figure 1, A and B, and data not shown). IHB cells do not express the CD43 and Mac-1 markers typical for B-1 or immature B cells (data not shown). IHB cells express CD5 at a level higher than that detected on blood B cells but lower than observed on PC B cells (Figure 1B). Higher CD5 levels are indicative of conventional B cell activation (10). IHB cells express CD23 but at a lower level than splenic or blood B cells. CD21 surface expression is also slightly lower for IHB than for splenic B cells but higher than for blood B cells (Figure 1B). Taken together, with regard to expression of these markers, liver $B$ cells are most similar to follicular splenic B cells.

Hepatic B cells are functionally competent. As liver is often regarded as a destination for dying lymphocytes (11), we tested whether IHB cells are proapoptotic using annexin $\mathrm{V}$, which binds to phospholipid phosphatidylserine (PS) that translocates from the inner to the outer layer of the cellular membrane as cells undergo apoptosis. Annexin $\mathrm{V}$ bound up to $30 \%$ of hepatic B cells compared with approximately $15 \%$ of splenic B cells (Figure 1C and data not shown). Thus, most liver $\mathrm{B}$ cells do not show a predisposition to apoptosis, and the higher number of apoptotic cells in liver compared with spleen might be related to differences in lymphocyte isolation.

The proliferative capacity of $\mathrm{B}$ lymphocytes in response to mitogenic and B cell receptor cross-linking stimuli is an important functional characteristic that differs substantially for B cell subsets (12-14). We compared hepatic and splenic B cells for their extent of proliferation and upregulation of costimulatory molecules, such as CD86 (B7.2) and MHCII, in response to various stimuli. The proliferative response of IHB cells was very similar to that of splenic B lymphocytes (Figure 1D); the response to Toll-like receptor 4, RP105, and CD40 stimulation is the same whereas response to IgM cross-linking is greater in the absence but not in the presence of IL-4. The difference noted may reflect better survival of IHB cells in culture without an exogenous survival factor like IL-4 and is consistent with an activated status of IHB cells suggested by CD5 upregulation (Figure 1B). A similar extent of upregulation of MHCII, CD86, and CD5, induced by tested stimuli, was demonstrated for liver and splenic B cells (Figure 1, B and D, and data not shown). 


\section{Table 1}

Sequences of $V_{H} D_{H} J_{H}$ junctional regions of Ig gene rearrangements in $B$ cells from neonatal spleen

\begin{tabular}{|c|c|c|c|c|c|}
\hline V & $\mathrm{P}, \mathrm{N}$ & D & $\mathrm{P}, \mathrm{N}$ & JH & Comments \\
\hline \multicolumn{6}{|l|}{ Neonatal spleen } \\
\hline TGT GCA AGA & $\mathbf{T}$ & CT GGG AC & & T TAC TAT GCT ATG GAC TAC TGG GGT & $V_{H} 1, D q 52, J_{H} 4, p$ \\
\hline TGT GCA AGA & GAG GGC & CTA TGA T T & & AT TAC TAT GCT ATG GAC TAC TGG GGT & $V_{H} 5, D s p 2.2, J_{H} 4, n p$ \\
\hline TGT GCA AGA & & TAT GAT TAC GA & & C TAC TGG TAC TTC GAT GTC TGG GGC & $V_{H} 1, D s p 2.2, J_{H} 1, p$ \\
\hline TGT GCA AGA C & & AT GGT AA & & C TAC TGG TAC TTC GAT GTC TGG GGC & $V_{H} 5, D s p 2.1,5,7, J_{H} 1, p$ \\
\hline TGT GCA A & & TC TAT GAT GGT T & & AC TAC TAT GCT ATG GAC TAC TGG GGT & $V_{H} 1, D s p 2.9, J_{H} 4, p$ \\
\hline TGT GCA AG & & T TAC TAC GGT AGT A GC & & TAC TAT GCT ATG GAC TAC TGG GGT & $V_{H} 10, D f 116.1, J_{H} 4, p$ \\
\hline TGT GTA AGA & & TGG & & TAC TAT GCT ATG GAC TAC TGG GGT & $V_{H} 1, D ?, J_{H} 4, p$ \\
\hline TGT AGT AG & & C & & TAC TGG TAC TTC GAT GTC TGG GGC & $V_{H} 6, D ?, J_{H} 1, p$ \\
\hline TGT GCA AGA & & TTA CTA CGG CTA C & & AC TAT GCT ATG GAC TAC TGG GGT & $V_{H} 1, D f 16.2, J_{H} 4, p$ \\
\hline TGT GC & & C TAC TAT AGG TAC G & & AC TAT GCT ATG GAC TAC TGG GGT & $V_{H} 5, D s p 2.10,11, J_{H} 4, p$ \\
\hline TGT GCA AG & & T TAC TAC GGT AGT A & & AC TGG TAC TTC GAT GTC TGG GGC & $V_{H} 1, D f 116.1, J_{H} 1, p$ \\
\hline TGT GCA AGA & GAT AT & T TAC TAC GGT AGT AG & & C TAC TGG TAC TTC GAT GTC TGG GGC & $V_{H} 7$, Dfl16.1, J $J_{H}, p$ \\
\hline TGT GTA AGA & G & AC TAC GGT AGT AGC & & TAC TAT GCT ATG GAC TAC TGG GGT & $V_{H} 2, D f 116.1, J_{H} 4, \mathrm{p}$ \\
\hline TGT GCA AGA & & TAT G & & GT AAC TAT GCT ATG GAC TAC TGG GGT & $V_{H} 5, D s p 2.1,5,7, J_{H} 4, p$ \\
\hline TGT GCA AGA & & TAT GGT AA & & C TAC TGG TAC TTC GAT GTC TGG GGC & $V_{H} 1, D s p 2.1,5,7, J_{H} 1, p$ \\
\hline TGT GCA AGA & & TAT GGT AA & & C TAC TGG TAC TTC GAT GTC TGG GGC & $V_{H} 5, D s p 2.1,5,7, J_{H} 1, p$ \\
\hline TGT GCA AG & & TA TGG TAA CTA & $\mathbf{T}$ & AT TAC TAT GCT ATG GAC TAC TGG GGT & $V_{H} 1, D s p 2.8, J_{H} 4, n p$ \\
\hline TGT GCA AGA & & T GGT A & & AT TAC TAT GCT ATG GAC TAC TGG GGT & $V_{H} 5, D s p 2.1,5,7, J_{H} 4, \mathrm{np}$ \\
\hline TGT GCC AGA & & AAC $\mathrm{T}$ & & AT TAC TAT GCT ATG GAC TAC TGG GGT & $V_{H} 2, D s p 2.1,5,7, J_{H} 4, p$ \\
\hline TGT GCA AG & GG & AT TAC TAC GGT AGT AGC & & TAC TAT GCT ATG GAC TAC TGG GGT & $V_{H} 5$, Dfl16.1, JH $4, \mathrm{p}$ \\
\hline TGT GCA A & & TC TAC TAT GGT TAC GA & & CTAC TGG TAC TTC GAT GTC TGG GGC & $V_{H} 10, D s p 2.3,4, J_{H} 1, p$ \\
\hline TGT GCA A & & TC TAC TAT GAT TAC G & & AC TAT GCT ATG GAC TAC TGG GGT & $V_{H} 1, D s p 2.2, J_{H} 4, p$ \\
\hline TGT GCA AGA & & GAT GG & & T TAC TAT GCT ATG GAC TAC TGG GGT & $V_{H} 7, D s p 2.9, J_{H} 4, p$ \\
\hline TGT GCA AGA & & GGC TAC & GG & C TAC TGG TAC TTC GAT GTC TGG GGC & $V_{H} 1, D f l 16.2, J_{H} 1, p$ \\
\hline TGT GCA AGA C & & G GT A & & AC TGG TAC TTC GAT GTC TGG GGC & $V_{H} 5, D s p 2.1,5,7, J_{H} 1, \mathrm{np}$ \\
\hline TGT GCA AGA & & TTA CTA CGG CT & & A CAC TAT GCT ATG GAC TAC TGG GGT & $V_{H} 1, D f 16.2, J_{H} 4, p$ \\
\hline TGT GCA AGA C & & AT GGT A & & AC TAT GCT ATG GAC TAC TGG GGT & $V_{H} 5, D s p 2.5, J_{H} 4, p$ \\
\hline TGT GCA AGA & & TGG & & TAC TGG TAC TTC GAT GTC TGG GGC & $V_{H} 1, D ?, J_{H} 1, p$ \\
\hline TGT GCA AGA & & CT ATG GTA ACT AC & & G TAC TTC GAT GTC TGG GGC & $V_{H} 5, D s p 2.1, J_{H} 1, \mathrm{np}$ \\
\hline
\end{tabular}

The $V_{H} D_{H} J_{H}$ joints are shown from the codon encoding the second cysteine (position 104) of the $V_{H}$ gene and extending to the conserved glycine of the $J_{H}$ region. The sequences were analyzed using DnaPlot. Nucleotides not encoded in the germline, called either $\mathrm{N}$ nucleotides $(55,56)$ or $\mathrm{P}$ nucleotides $(57)$, are listed in the $\mathrm{P}, \mathrm{N}$ column. Sequences of the $\mathrm{IgH}$ locus are categorized into productive (p) or nonproductive (np) in the Comments column and assigned $V_{H}$ family, $D_{H}$ element, and $J_{H}$ elements. $D_{H}$ sequences were assigned to published $D_{H}$ segments (58) if there was homology of at least 4 nucleotides. D? indicates that the respective $D$ element could not be unambiguously assigned to a particular gene. Bolded text indicates $\mathrm{P}, \mathrm{N}$ nucleotides.

IHB cells resemble splenic B2 cells and are not of embryonic liver origin. B cells in adult liver may represent residual hepatic B cell generation from embryonic liver. Alternatively, IHB cells may be BM derived as are splenic $B$ cells in an adult organism. To address the origin of IHB cells, we performed genetic analyses of their VDJ rearrangements. Few insertions of nontemplated $(\mathrm{N}, \mathrm{P})$ nucleotides are seen in the VDJ junctions of neonatal B cells generated in the embryonic liver, which is similar to what has been reported for B1 cells (15-17). In contrast, adult splenic and blood B cells have extensive nontemplated nucleotide additions $(18,19)$. We compared CDR3 sequences derived from pooled adult liver lymphocytes with those derived from splenic cells of 2-day-old mice or adult mouse blood B cells. Adult IHB cells markedly differed from neonatal B cells and resembled splenic B2 cells or recirculating blood B cells in their VDJ joint sequence (Tables 1 and 2 ). The average number of $\mathrm{N}, \mathrm{P}$ nucleotides in neonatal B cells was 0.5 for the $V D$ junction and
0.1 for the $D J$ junction (Table 1 ). This is notably different from 3.5 (or 4.5 ) for the $V D$ and 4.4 (or 3.4) for the $D J$ junctions of $\mathrm{B}$ cells in the adult liver (or blood) (Table 2). Interestingly, adult liver and blood B cells also appeared different in the length of their VD and $D J$ junctions; this difference is on the border of being statistically significant ( $P=0.1$, Student's $t$ test). IHB cells have fewer N,P nucleotides in their $V D$ joints than in their $D J$ joints, the converse of what is reported for conventional adult B2 cells (18). The difference in the length of N,P insertions in the IHB and adult blood B cells might be a result of IHB cell selection. In addition, the difference strengthens the notion that liver B cells represent a true IH population with no significant contamination by peripheral blood B cells (see also Methods).

$B$ cell role in hepatic fibrosis. Every $\mathrm{CCl}_{4}$ administration causes a pronounced necroinflammatory liver injury that is followed by a chronic repair response. This model has an advantage over many 
Table 2

Sequences of $V_{H} D_{H} J_{H}$ junctional regions of Ig gene rearrangements in $B$ cells from adult liver and adult blood

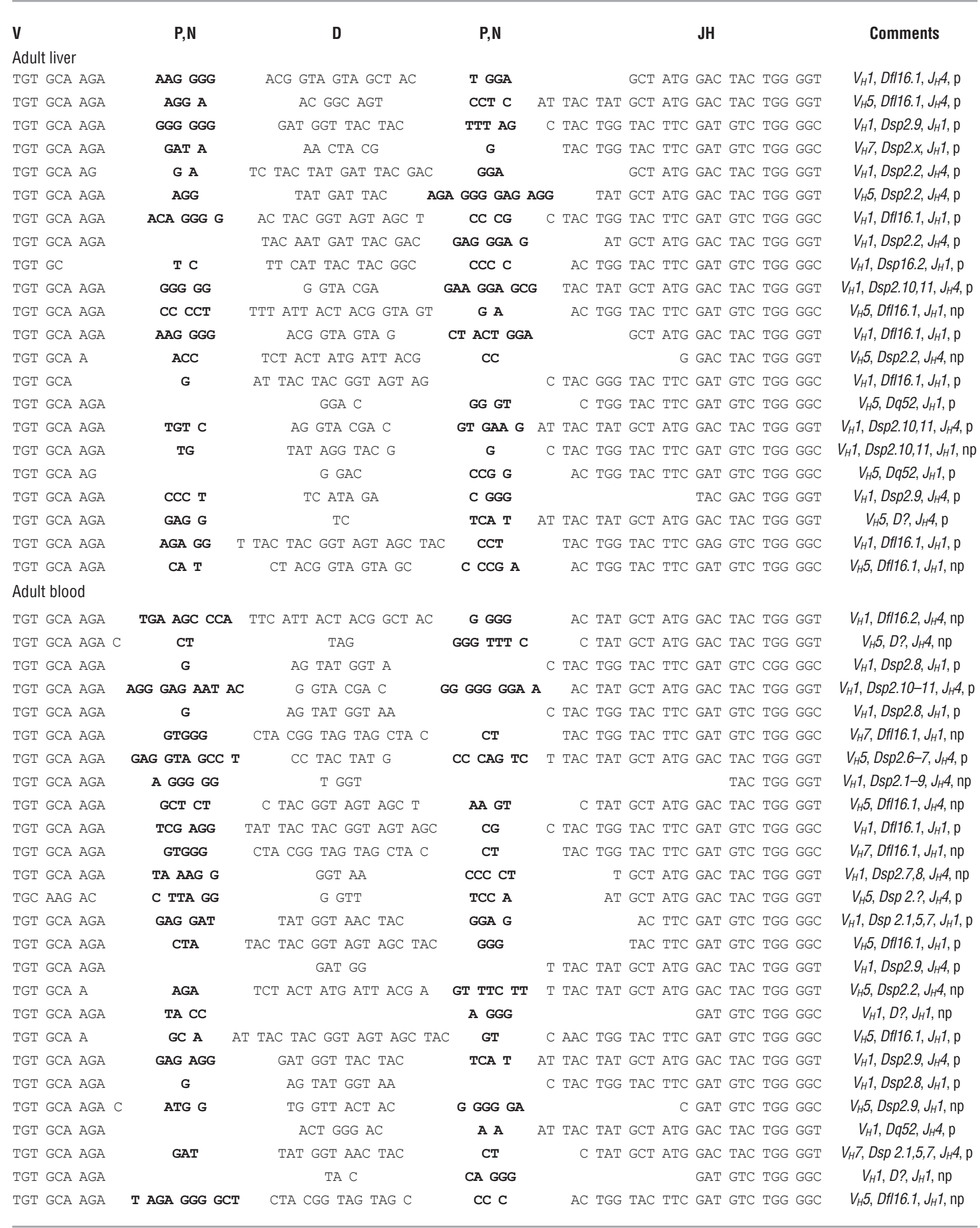


A
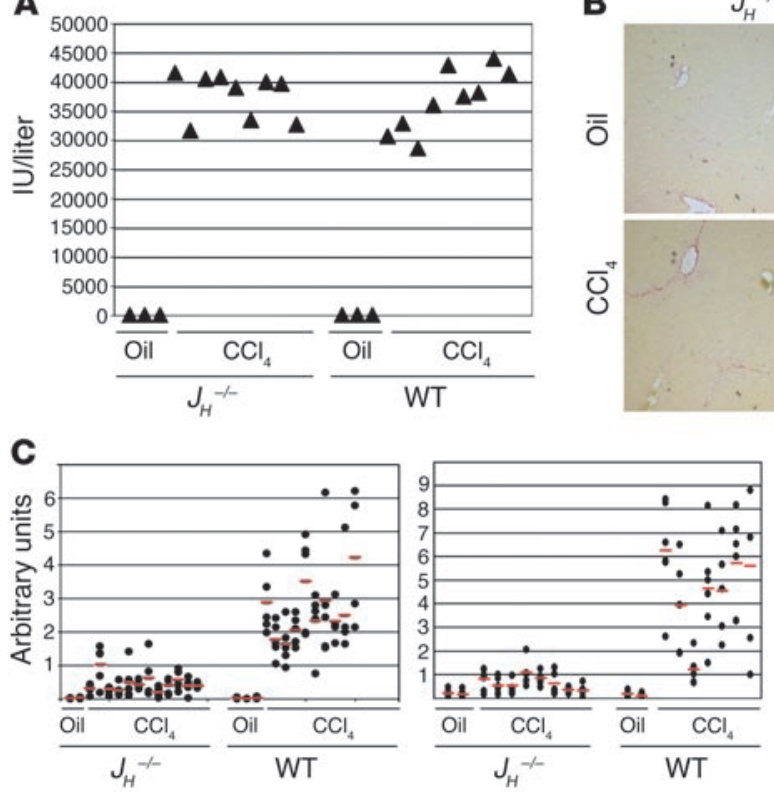

B
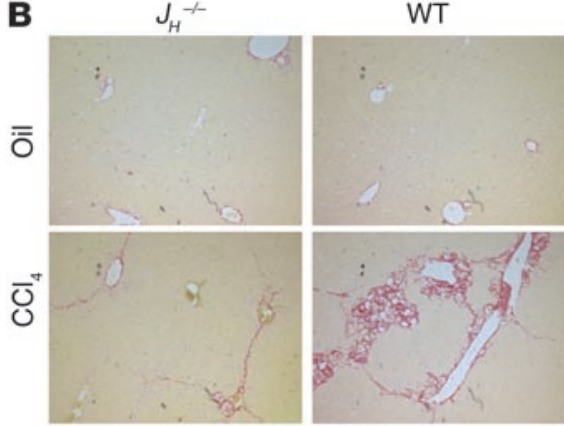

D

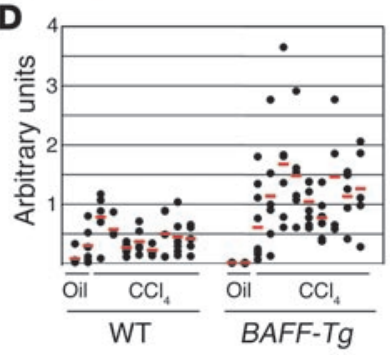

Figure 2

The degree of liver fibrogenesis is proportionate to B cell numbers. Mice were gavaged with $3.5 \mathrm{ml} / \mathrm{kg}$ (A and $\mathbf{B}$ and $\mathbf{C}$, left panel) or $1.75 \mathrm{ml} / \mathrm{kg}\left(\mathbf{C}\right.$, right panel, and $\mathbf{D}$ ) of $\mathrm{CCl}_{4}$ or mineral oil. Each plot represents 1 experiment. (A) $J_{H^{-/}}$and BALB/c WT control mice were bled 24 hours after a single $\mathrm{CCl}_{4}$ or oil administration, and ALT levels were measured. A representative experiment out of 3 is shown. (B-D) One week after the sixth weekly treatment of oil or $\mathrm{CCl}_{4}$, mice were sacrificed, and collagen-specific Sirius red staining of liver sections was performed to quantify interstitial collagen deposition in $J_{H^{--}}$and WT BALB/c mice (C) or in WT C57BL/6 and BAFF-Tg mice (D). Magnification, $\times 50$. In each case, a representative experiment out of at least 2 is shown. A column of dots represents a series of sections from 1 animal; mean values are depicted as red bars.

widely utilized liver injury models (e.g., schistosome, LPS, ConA) because the toxic insult induces general hepatotoxicity rather than a priori targeting a defined part of the immune system. Yet we found $\mathrm{B}$ cells in the liver to be particularly sensitive to $\mathrm{CCl}_{4}$ application. IHB cell numbers dropped approximately 10-fold 1 day after a $\mathrm{CCl}_{4}$ treatment as opposed to other IH lymphocytes (NKT cells, T cells), which remained unaffected at this time point (data not shown). By day 5 after a $\mathrm{CCl}_{4}$ injection, B cell numbers recovered (data not shown).

To test whether B cells have a role in liver injury and repair, we used B cell-deficient mice in $\mathrm{CCl}_{4}$-induced hepatotoxicity studies. The B cell-deficient mouse strain chosen for analysis carries a targeted deletion in the $\mathrm{J}_{\mathrm{H}}$ region of the immunoglobulin heavy chain gene, which precludes assembly of a coding heavy chain gene and thus prevents B cell and antibody generation (20). These B cell-deficient mice will be referred to herein as $J_{H^{-1-}}$ mice.

The extent of liver injury, assessed by the release of the hepatocyte-specific enzyme alanine aminotransferase (ALT) into serum 24 hours after a $\mathrm{CCl}_{4}$ treatment and by histological analysis, was similar in $\mathrm{J}_{H^{-/}}$and WT BALB/c mice (Figures 2A and 3; Supplemental Figure 1; supplemental material available online with this article; doi:10.1172/JCI24798DS1). Interestingly, however, there was a large difference in the amount of collagen fibers accumulating; $J_{H^{-1}}$ - mice had about 6 - to 8 -fold less interstitial collagen deposition compared with WT mice 1 week after the sixth weekly dose of either 1.75 or $3.5 \mathrm{ml} / \mathrm{kg} \mathrm{CCl}_{4}$ (Figure 2, B and C). No significant changes in the number or location of $\mathrm{F} 4 / 80^{+}$macrophages and ever, the BAFF-Tg mice had about twice the amount of collagen deposits as their WT C57BL/6 counterparts (Figure 2D).

$B$ cell-deficient and WT mice respond differently to a single $\mathrm{CCl}_{4-}$ induced injury. To understand what acute effects trigger changes in collagen deposition after 6 weeks of treatment, the kinetics of tissue changes were analyzed in liver sections of $\mathrm{B}$ cell-deficient and control mice 1,3 , and 5 days after a single $\mathrm{CCl}_{4}$ challenge. Interestingly, TUNEL staining detecting apoptotic cells showed that despite similar initial injury at day $1, J_{H^{-/-}}$mice cleared apoptotic cells completely by day 3 , whereas in WT mice, some dying cells were still detected even 5 days after injury (Figure 3 and Supplemental Figure 1). When staining sections for the tissue macrophage-specific marker F4/80, we found that as early as day 1 , there was a small increase in macrophage numbers in $J_{H^{-1}}$ compared with WT mice, which became very substantial by days 3 and 5 (Figure 3 and Supplemental Figure 1). Thus, it seems that in the absence of $\mathrm{B}$ cells, macrophages are better able to clear dying hepatocytes. As the major cellular source for collagen fibers is a population of myofibroblasts (24), we also monitored $\alpha$-SMA that marks activated hepatic stellate cells/myofibroblasts in the injured liver. Myofibroblasts were first detectable at day 3 at levels similar to those in B cell-deficient and control mice. By day 5 , however, WT mice showed many more myofibroblasts (Figure 3 and Supplemental Figure 1). Higher efficiency of macrophages to remove dying hepatocytes may have reduced myofibroblast activation and eventually resulted in the lower collagen deposition. In a recent study (25), macrophages were shown to play distinct, 

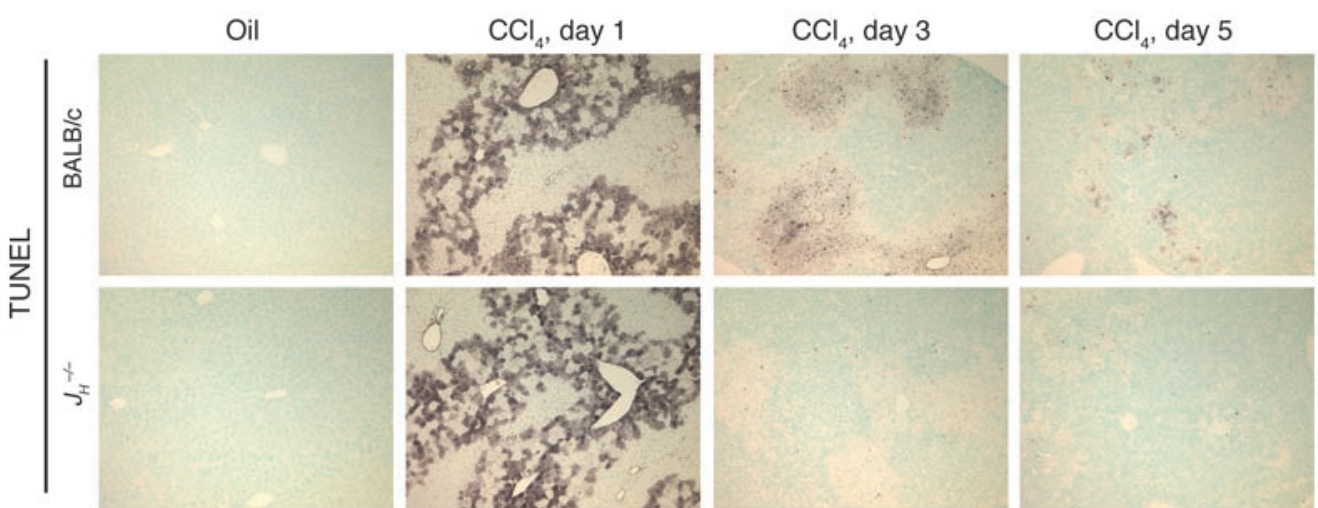

\section{Figure 3}

B cell-deficient mice have altered kinetics of response to a $\mathrm{CCl}_{4}$-induced liver injury. Mice of the genotype indicated were gavaged once with 1.75 $\mathrm{ml} / \mathrm{kg}$ of $\mathrm{CCl}_{4}$ or with mineral oil. Either 1,3 , or 5 days after treatment, mice were sacrificed, and immunohistochemical analyses of liver sections were performed. Magnification for apoptotic cell-specific TUNEL, macrophage-specific F4/80, and myofibroblast-specific
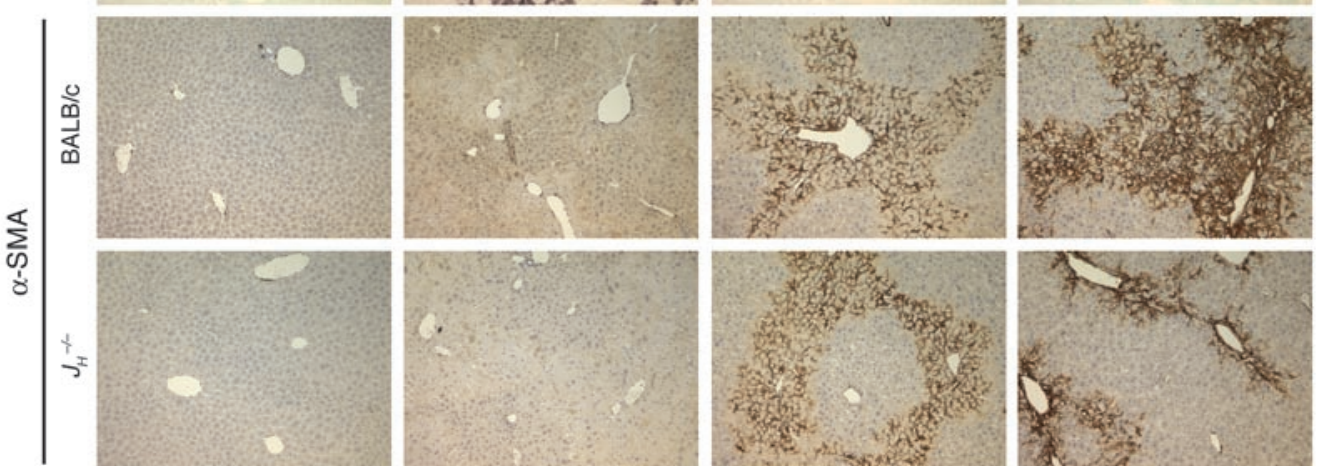
$\alpha$-SMA stainings, $\times 100$.
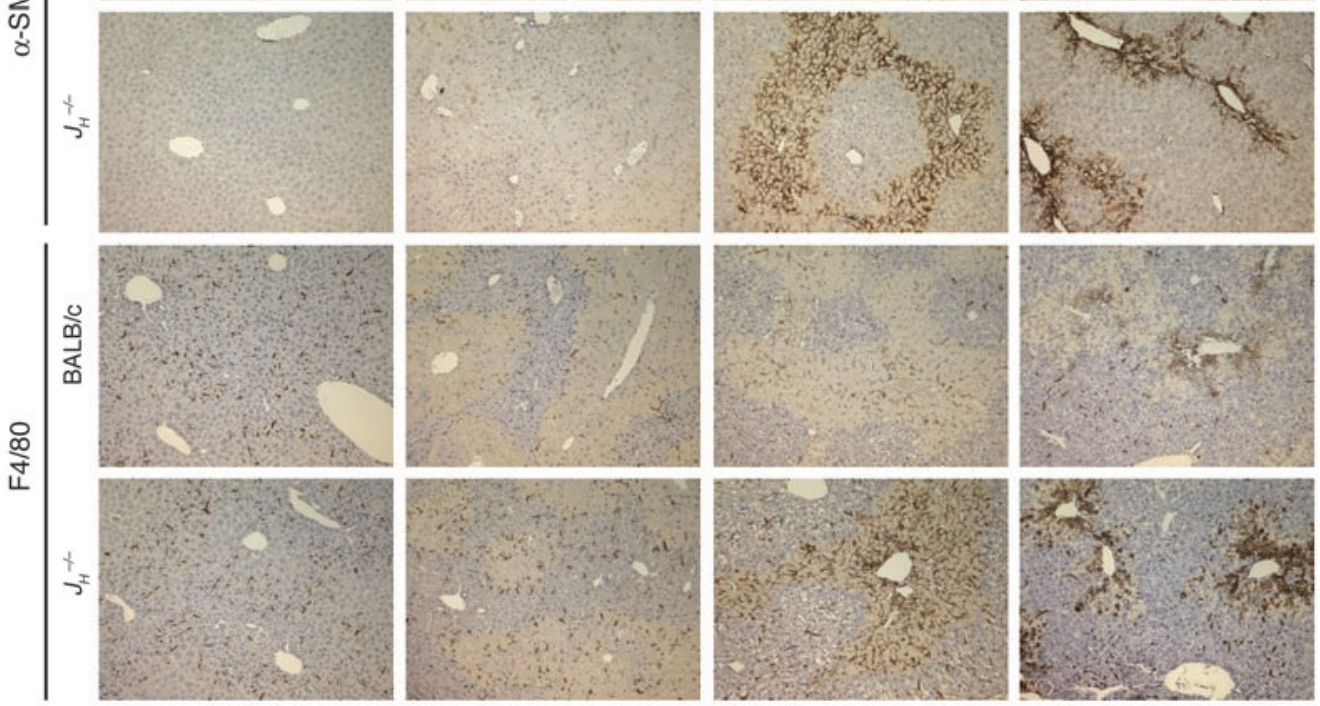

opposing roles during liver injury and repair. It appears that in the absence of B cells, those macrophages that contribute to recovery from inflammatory scarring are preferentially activated.

$B$ cell-derived soluble factors have the potential to stimulate collagen production by activated hepatic stellate cells. To investigate whether soluble factors produced by activated B cells can directly affect proliferation and collagen production by myofibroblasts, we cultured T6-HSC (26), a rat cell line derived from activated hepatic stellate cells, in the presence of supernatants from purified splenic rat B cells activated with LPS. We chose LPS as the most likely agent reaching the liver of $\mathrm{CCl}_{4}$-gavaged mice through the portal system. LPS mimics polyclonal T cell-independent activation of $\mathrm{B}$ cells. We used human recombinant TGF- $\beta$, a known regulator of fibrogenesis, as a positive control. Proliferation was measured by $\left[{ }^{3} \mathrm{H}\right]$-thymidine and de novo collagen synthesis by $\left[{ }^{3} \mathrm{H}\right]$-proline incorporation (Figure 4). B cell supernatants induced increases in collagen synthesis similar to human TGF- $\beta$ at $10 \mathrm{ng} / \mathrm{ml}$ with LPS having an intermediate effect (Figure 4). Thus, soluble factors produced by stimulated B cells can induce collagen synthesis by hepatic stellate cells. However, the magnitude of in vitro response of already activated hepatic stellate cells (T6-HSC) to a known profibrogenic cytokine, TGF- $\beta$, is substantially less than that observed in vivo (data not shown). For this reason, we do not believe that use of a cell line is the optimal approach to unravel in vivo mechanisms of B cell-dependent effects of fibrogenesis. It is noteworthy that in vitro data do not rule out alternative B cell-mediated effects on HSCs, such as cell-cell interaction or indirect influence.

$\mathrm{CD}^{+}, \mathrm{CD} 8^{+}$, and $\gamma \delta \mathrm{T}$ cells do not influence hepatic fibrosis to a significant degree. To assess whether mice deficient in $\mathrm{T}$ cells also have a defect in fibrogenesis, we performed a series of $\mathrm{CCl}_{4}$-induced liver injury experiments with mice that lack both $\mathrm{B}$ and $\mathrm{T}$ cells $\left(R A G 2^{--}\right), \mathrm{CD}^{+} \mathrm{T}$ cells $\left(A \beta^{-/-}\right), \mathrm{CD}^{+} \mathrm{T}$ cells $\left(\beta 2 \mathrm{~m}^{-/-}\right)$, and $\gamma \delta \mathrm{T}$ cells $\left(T C R \delta^{-/-}\right)$. For every mouse mutant strain, a control strain of the same genetic background was used (Table 3). Of these, only $R A G 2^{-/-}$mice showed dissimilar amounts of collagen deposition following long-term treatment with $\mathrm{CCl}_{4}$ compared with appropriate WT counterparts (Figure 5 and data not shown). RAG2-/mice, lacking all lymphocytes that require DNA rearrangement to assemble their receptors, showed a 3 - to 4 -fold reduction in 

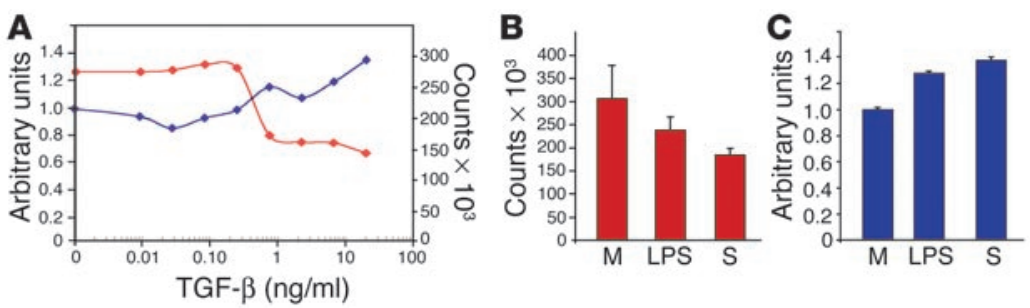

\section{Figure 4}

Collagen production by T6-HSC can be stimulated by B cell-derived soluble factors. T6-HSC cells were seeded at $25 \%$ confluence in a 96 -well plate in RPMI, $5 \%$ FBS, penicillin, streptomycin. After 24 hours, an equal volume of B cell-conditioned medium was added with $\left[{ }^{3} \mathrm{H}\right]$-thymidine (to measure proliferation) or with $\left[{ }^{3} \mathrm{H}\right]$-proline (to measure de novo collagen synthesis). After 18 hours, the amount of incorporated ${ }^{3} \mathrm{H}$ was quantified. Collagen synthesis per cell is expressed in arbitrary units; we took the ratio of radioactive counts of $\left[{ }^{3} \mathrm{H}\right]$-proline/radioactive counts of $\left[{ }^{3} \mathrm{H}\right]$-thymidine, considering this ratio equal to 1 in the absence of TGF- $\beta$. Each treatment was performed in triplicate. A representative experiment out of 3 is shown. (A) Human TGF- $\beta$ that is recognized by rat TGF- $\beta$ receptor was added at different concentration to the culture of T6-HSC cells. $\left[{ }^{3} \mathrm{H}\right]$-thymidine incorporation is shown in red. Collagen synthesis as assessed by the rate of $\left[{ }^{3} \mathrm{H}\right]$-proline incorporation is shown in blue. T6-HSC proliferation (B) and collagen synthesis relative to cell number as assessed by the ratio of $\left[{ }^{3} \mathrm{H}\right]-$ proline/[ $\left.{ }^{3} \mathrm{H}\right]$-thymidine incorporation $(\mathbf{C})$ is measured in medium alone $(\mathrm{M})$, with LPS, and with supernatant of B cells cultured with LPS (S). B cells were cultured for 3.5 days prior to harvesting supernatant. Red and blue bars show a mean from triplicate values; error bars show standard deviation.

interstitial collagen accumulation compared with WT mice (Figure $5 \mathrm{~B}$ ). This resembles the result obtained in mice lacking only $\mathrm{B}$ cells and does not imply a prominent role for T cells in the $\mathrm{CCl}_{4}$ model of liver fibrosis.

$B$ cell role in liver fibrosis is antibody independent. B cells can mediate local effects, such as antigen presentation, cytokine release, and/or cell-cell contact regulated by costimulatory molecules, and longrange effects via antibodies. As T cell-deficient animals (see above) did not show any differences in collagen deposition, B cell antigen presentation to T cells is unlikely to influence liver fibrosis.

To determine whether $\mathrm{B}$ cell regulation of liver fibrosis requires immunoglobulin production, we took advantage of 2 mouse strains that have normal numbers of B cells but either lack Ig in their serum or have Ig levels severely reduced. Mice expressing Epstein-Barr virus-derived protein LMP2a from a gene incorporated at the place of $J$ elements of the $I g H$ locus $\left(D_{H} L M P 2 a\right.$ allele; ref. 27) lack both surface and circulating immunoglobulin whereas mice expressing mIgM-Tg on the $J_{H^{-1}}$ background encode surface but not secreted $\operatorname{Ig}(28)$.

As shown in Figure 6A, following 6 weekly treatments of 1.75 $\mathrm{ml} / \mathrm{kg} \mathrm{CCl}$, similar levels of collagen deposition were noted in mice expressing Epstein-Barr virus-derived LMP2a protein and their WT BALB/cAnNCrlBr controls. Moreover, $\operatorname{mIgM-Tg}\left(\mathrm{J}_{H^{-1}}\right)$ mice expressing surface but not secreted $\operatorname{Ig}(28)$ showed the same degree of $\mathrm{CCl}_{4}$-induced liver fibrosis as WT control BALB/c mice (Figure 6B). Thus, B cell effects on the pathology of $\mathrm{CCl}_{4}$-induced liver fibrosis are antibody independent. It is noteworthy that the degree of fibrosis in WT BALB/c mice in these experiments was lower than in previous ones (Figures 2, 5, and 6), possibly because of different housing conditions and/or concurrent infection of these animals. Both LMP2 $a$ and IgM mouse colonies were positive for Helicobacter hepaticus; therefore, these mice as well as corresponding WT strains were kept in quarantine facilities.

\section{Table 3}

\section{Discussion}

In this work we demonstrate that IHB cells represent a sizable population with phenotypic and functional characteristics resembling those of conventional B2 cells. IHB cells express CD5 at somewhat higher levels than conventional B2 cells, and they proliferate better in response to IgM cross-linking without supplementing IL-4 in vitro (Figure 1), implying activated status of IHB cells. Despite the fact that adult liver has been known to contain c-kit ${ }^{+}$pluripotent hematopoietic stem cells that could give rise to multilineage leukocytes $(29,30)$, most B cells in the adult liver appear to be BM-derived, in contrast to selfpropagating embryonic liver-derived B1 lineage cells (4). IHB cells are likely of BM origin; VDJ junctions of IHB cells contained extensive $\mathrm{N}$ nucleotide insertions, with total average length similar to conventional B2 cells (Tables 1 and 2). Notably, expression of terminal deoxyribonucleotidyl transferase (TdT), the enzyme responsible for $\mathrm{N}$ nucleotide insertion, has not been studied in adult liver (31). Thus, the formal but unlikely possibility exists that adult liver $\mathrm{B}$ cells are generated in the liver with $\mathrm{N}$ nucleotide insertions (perhaps in a TdT-dependent fashion).

Here we show that B cells play an important antibody-independent role in the development of liver fibrosis, adding another disease model likely dependent on local B cell function. In the presence of B cells, liver fibrosis develops to a much greater extent, indicating that $\mathrm{B}$ cells are nonredundant participants in liver disease progression. An imperative role of B cells has also been demonstrated for autoimmune diabetes in NOD mice. B cell-deficient NOD.Igunull and B cell-depleted NOD mice did not develop insulitis or insulin-dependent diabetes mellitus, supporting the idea that B cells are critical for the initiation and/or activation of autoreactive $\mathrm{T}$ cells $(32,33)$. B cells were also shown to be required for lupus nephritis in the polygenic, fasintact, and fas-deficient MRL models of systemic autoimmunity $(28,34,35)$. In both cases, an antibody-independent mechanism turned out to be crucial for B cell involvement $(28,36)$.

In our experiments, we used mice constitutively devoid of $B$ cells to study B cell involvement in fibrotic pathology. Although normal in gross physiology, B cell-deficient mice lack follicular dendritic networks (37-39), follicle-associated epithelium in the intestinal Peyer's patches (40), and a noncanonical subset of NKT

Mouse strains used in the study ${ }^{A}$

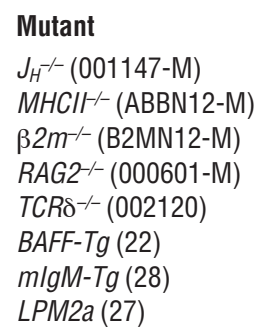

\section{Control}

BALB/C (BALB)

C57BL/6Tac (B6)

C57BL/6Tac (B6)

$\mathrm{BALB} / \mathrm{C}(\mathrm{BALB})$

C57BL/6 (000664)

C57BL/6 (000664)

$\mathrm{BALB} / \mathrm{C}(\mathrm{BALB})$

$\mathrm{BALB} / \mathrm{CAnNCrIBr}$

\section{Commercial source Taconic Taconic Taconic Taconic Jackson Laboratory Jackson Laboratory Taconic Charles River Laboratories}

\footnotetext{
${ }^{A}$ Reference or commercial source is provided for each strain.
} 
A

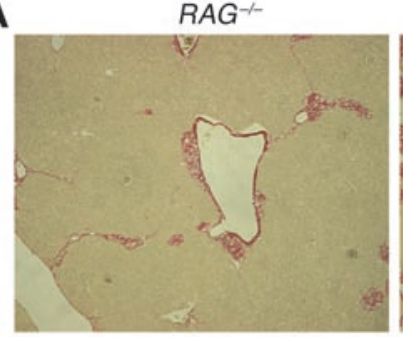

B

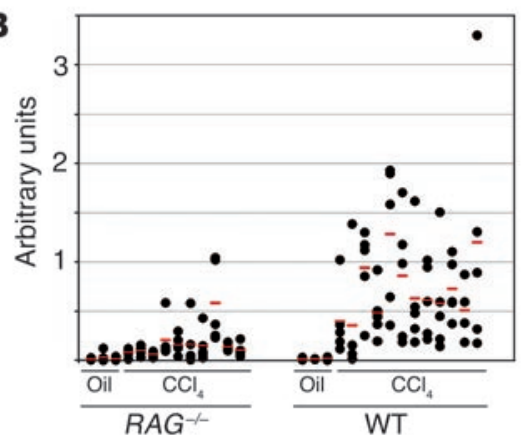

WT

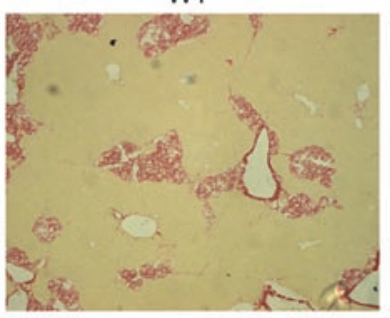

cells (41). Mice lacking B cells also have defects in $\mathrm{CD}^{+} \mathrm{T}$ cell function (42) and perhaps some other as yet undescribed developmental/functional deficiencies. Thus, the results obtained with the B cell-deficient mice cannot alone be interpreted to indicate that $\mathrm{B}$ cells directly affect the pathogenesis of liver fibrosis. Since $\mathrm{T}$ cell-deficient mice do not show any difference in the development of liver fibrosis (data not shown), a CD4 ${ }^{+} \mathrm{T}$ cell defect is unlikely to account for the strongly attenuated liver fibrosis observed in the $J_{H^{-1}}$ mice. However, a B cell-dependent NKT cell subset that expresses V $\alpha 19$ containing invariant TCR (41), resident in murine liver (43), might contribute to the reduced fibrosis noted in the B cell-deficient mice. NKT cells are known for their ability to respond in a rapid manner and to produce both TH1- and TH2type cytokines (44). Such qualities allow NKT cells to participate in immune response regulation (44). We did not find any pronounced differences in liver fibrosis development in $C D 1^{-/-}$mice (data not shown) that lack conventional V 14 TCR NKT cells. Unfortunately, there is no mouse mutant available that allows one to address the role of noncanonical V $\alpha 19$ invariant NKT cells in

\section{Figure 5}

$R A G^{-/-}$mice show reduction in fibrosis development. $R A G^{-/-}$or WT $\mathrm{BALB} / \mathrm{c}$ mice were gavaged with $1.75 \mathrm{ml} / \mathrm{kg}$ of $\mathrm{CCl}_{4}$ or with mineral oil. One week following the sixth weekly treatment, mice were sacrificed; collagen-specific Sirius red staining of liver sections was performed (A), and interstial collagen deposition was quantified (B). A column of dots represents a series of sections from 1 animal; mean values are shown in red bars. Magnification for Sirius red staining, $\times 50$.

liver fibrosis. Nonetheless, as $R A G^{-/-}$animals show inhibition of fibrosis to an extent similar to that of B cell-deficient mice, a role for cell types that require gene rearrangement for their development ( $\mathrm{B}$ and $\mathrm{T}$ cells of various lineages) is implied. Thus, together the data suggest that either non-CD1 restricted NKT cells that require B cells for their development (41) or B cell autonomous function has a role in the fibrosis manifested in the $\mathrm{CCl}_{4}$-induced hepatotoxicity model.

By using 2 previously generated mouse strains (LMP2a insertion and $m I g M-T g$ mice) deficient in immunoglobulin production, we have shown that antibodies are not required to develop $\mathrm{CCl}_{4}$ induced liver fibrosis. LMP2a mice have normal B cell numbers and completely lack both secreted antibodies and surface expression of immunoglobulin (27). LMP2A does not only mimic BCR signaling, but triggers additional signaling pathways $(45,46)$. To eliminate the possibility that the effects observed in $L M P 2 a$ mice are compensated for by LMP2a signaling, we assessed fibrogenesis in the $m \operatorname{IgM}-\mathrm{Tg}\left(\mathrm{J}_{\mathrm{H}^{-}}{ }^{-}\right)$mice. $\operatorname{mIgM}-\mathrm{Tg}\left(\mathrm{J}_{\mathrm{H}^{-}}{ }^{-}\right)$mice express a surface Ig receptor and have 300- to 500-fold reduced antibody titers compared with normal mice (28). Both mouse lines developed liver fibrosis to an extent similar to that of controls. Thus, the B cell role in liver fibrosis pathology appears to be antibody independent, suggesting that it is mediated by functions (e.g., cytokine secretion and/or cellcell contact) of local B cells as opposed to potentially long-range effects mediated by B cells localized elsewhere in the organism. An antigen presentation role for B cells is unlikely to play a significant role in liver fibrosis as mice deficient in conventional $\mathrm{T}$ cells show fibrogenesis similar to that of their WT counterparts. Moreover, $L M P 2 a$ B cells do not have the ability to bind, internalize, and present antigens because they lack B cell receptors on the surface. Yet LMP2 a mice develop collagen deposits similar to those of WT mice. Together, these data suggest that liver tissue repair is affected by local B cell function, which may be mediated in part by the IHB
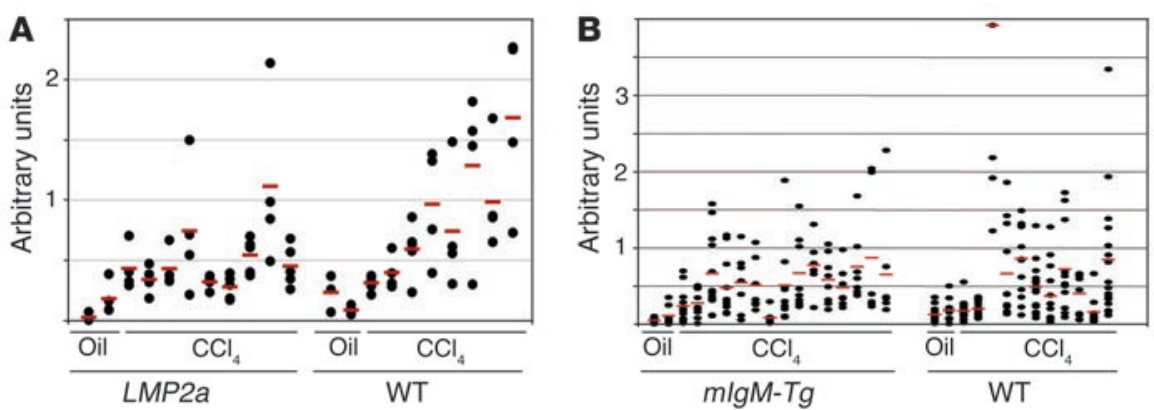

Figure 6

$\mathrm{B}$ cells mediate antibody-independent effects on $\mathrm{CCl}_{4}$-induced liver fibrosis. (A) Mice expressing Epstein-Barr virus-derived protein LMP2a from a gene incorporated at the place of $J$ elements of the $\mathrm{IgH}$ locus that lack both surface and circulating immunoglobulin, $(\mathbf{B}) \mathrm{mlgM}-\mathrm{Tg}\left(\mathrm{J}_{H^{-1}}\right)$ mice expressing surface but not secreted Ig, and corresponding WT control mice were gavaged with $1.75 \mathrm{ml} / \mathrm{kg}$ of $\mathrm{CCl}_{4}$ or with mineral oil. One week after the sixth weekly treatment, mice were sacrificed, collagen-specific Sirius red staining of liver sections was performed, and interstitial collagen deposition was quantified. A column of dots represents a series of sections from 1 animal; mean values are shown as red bars. 
cells defined herein. Formally, it is possible that B cells overwhelm clearance mechanism(s) in the liver. However, B cell numbers are very small compared with hepatocyte numbers.

Our results are in agreement with reports that the degree of hepatic damage in response to $\mathrm{CCl}_{4}$ was significantly milder in splenectomized compared with sham-operated rats (47) and in SCID mice on BALB/c background compared with appropriate controls (23). However, liver fibrosis induced by the Schistosoma mansoni parasite is increased in B cell-deficient compared with control mice (48). The differences in the fibrosis induction mechanism by repeated hepatocyte damage (as is the case for $\mathrm{CCl}_{4}$ and ANIT) or by low-level worm infection could explain the discrepancy.

$B$ cell function has also been associated with fibrosis in human skin and lung. B lymphocyte gene signature characterizes skin biopsies from systemic sclerosis patients (49). Moreover, a B cell line established from the lung tissue of a patient with scleroderma exhibits augmented proliferation and inflammatory responses that are likely to lead to fibrotic changes (50).

In sum, this study describes the isolation and characterization of $\mathrm{B}$ cell populations in adult liver and directly demonstrates an indispensable role of B cells in tissue repair following hepatic injury.

\section{Methods}

Mice. Unless otherwise stated, mice were kept in a specific pathogen-free mouse facility at Biogen Idec. All animal procedures were approved by Biogen Idec's Institutional Animal Care and Use Committee. Male mice of different strains (Table 3) had to weigh $20 \mathrm{~g}$ or more and be at least 6 weeks of age to be included in the study.

$\mathrm{CCl}_{4}$ and ANIT injury models. A mix of $\mathrm{CCl}_{4}$ (Sigma-Aldrich) with mineral oil (Sigma-Aldrich) was delivered by gavage in approximately $0.2 \mathrm{ml}$ with a 20 -gauge animal-feeding needle. Experiments were performed using a 3.5 $\mathrm{ml} / \mathrm{kg}$ or $1.75 \mathrm{ml} / \mathrm{kg}$ dose of $\mathrm{CCl}_{4}$. The latter dose was preferred because it reduced morbidity/mortality and still induced changes in serum ALT levels and collagen deposition comparable to the higher dose. For a longterm experiment, mice were gavaged once a week for 6 weeks. Short-term experiments included one $\mathrm{CCl}_{4}$ administration. ANIT (Sigma-Aldrich) was dissolved in mineral oil (Sigma-Aldrich) at $30 \mathrm{mg} / \mathrm{ml}$. Mice were gavaged with $50 \mathrm{mg} / \mathrm{kg}$ twice a week for 8 weeks.

Serum ALT levels were measured 24 hours after $\mathrm{CCl}_{4}$ administration. One week after the 6th weekly gavage or on the indicated day after a single gavage, mice were sacrificed and 3 different liver lobes were taken from each mouse and incubated in 4\% PFA in PBS for 2 days prior to embedding for immunohistochemical analysis.

Liver lymphocyte isolation. Mice were euthanized by $\mathrm{CO}_{2}$ inhalation. The hepatic portal vein was cannulated with a 25 -gauge needle and perfused with $10 \mathrm{ml}$ of cold PBS. After removal of the gall bladder, the liver was cut into segments and passed through a $70-\mu \mathrm{m}$ mesh cell strainer (BD Falcon; $\mathrm{BD}$ ) in $50 \mathrm{ml}$ of ice-cold RPMI, $5 \% \mathrm{FBS}$. The liver slurry was centrifuged at $300 \mathrm{~g}$ for 10 minutes at $4{ }^{\circ} \mathrm{C}$ in a $50-\mathrm{ml}$ tube per liver. The pellet was resuspended in $10 \mathrm{ml}$ of $0.02 \%$ collagenase IV (Sigma-Aldrich) in RPMI 1640 and left for 45 minutes at $37^{\circ} \mathrm{C}$. Ice-cold RPMI, $5 \% \mathrm{FBS}(30 \mathrm{ml})$ was added to each tube, then centrifuged for 3 minutes at $30 \mathrm{~g}$. The pellet was discarded. The supernatant was centrifuged for 10 minutes at $300 \mathrm{~g}$ at $4^{\circ} \mathrm{C}$. The cell pellet was resuspended in $6 \mathrm{ml}$ of ice-cold RPMI 1640 (or in 45\% Percoll [Amersham Biosciences]) and underlaid with $24 \%$ metrizamide (SigmaAldrich) in PBS (or with 70\% Percoll, respectively). A centrifugation at $1000 \mathrm{~g}$ for 20 minutes at $4{ }^{\circ} \mathrm{C}$ followed. Lymphocytes at the interface were harvested, washed with RPMI, $5 \%$ FBS, and used for further analyses.

The degree of IH lymphocyte contamination by blood lymphocytes is likely minimal, as the results (Tables 1 and 2 and data not shown) indicate a liver-specific increase in NKT cells and a different ratio of $\mathrm{N}$ nucleotide insertions at the $V D$ and $D J$ junctions in IHB lymphocytes (3.5 and 4.4) compared with blood B cells (4.5 and 3.4; see also Results).

Isolation of lymphocytes from spleen, blood, and PC. Spleens were minced through a nylon mesh (Cell Strainer, BD Falcon; BD) to obtain single cell suspensions in DMEM, 5\% FCS, and $2 \mathrm{mM}$ L-glutamine. Erythrocytes were lysed by incubating in lysis buffer $\left(140 \mathrm{mM} \mathrm{NH}_{4} \mathrm{Cl}, 17 \mathrm{mM}\right.$ Tris- $\mathrm{HCl}, \mathrm{pH}$ 7.65) for 3 minutes on ice. Blood was collected in EDTA-containing tubes (BD Biosciences - Pharmingen). To isolate blood lymphocytes, $200 \mu \mathrm{l}$ of blood was underlaid with Ficoll-Paque (Amersham Biosciences) and centrifuged at $1000 \mathrm{~g}$ at room temperature for 20 minutes. Lymphocytes were collected from the interface. The PC was washed with $5 \mathrm{ml}$ of DMEM, $5 \%$ FCS, and $2 \mathrm{mM}$ L-glutamine to collect PC leukocytes. Following these procedures, lymphocytes were washed twice in DMEM, 5\% FCS by $300 \mathrm{~g}$ centrifugation at $4{ }^{\circ} \mathrm{C}$ and resuspended in PBS/BSA/azide for flow cytometric analysis or in cell culture medium for proliferation studies.

Purification of rat B cells and T6-HSC culture. Splenocytes from 4-month-old Sprague-Dawley rats were purified using negative selection with anti-rat CD43 MACS beads according to manufacturer's protocol (Miltenyi Biotec). B cells ( $>95 \%$ purity, data not shown) were seeded at $3 \times 10^{6} \mathrm{cells} / \mathrm{ml}$ in RPMI 1640, 5\% FCS, $\beta$-mercaptoethanol, L-glutamine and cultured for 3.5 days with or without $4 \mu \mathrm{g} / \mathrm{ml}$ of Ultrapure LPS (InvivoGen.).

T6-HSC cells were seeded at $25 \%$ confluence in a 96 -well plate in RPMI, $5 \%$ FBS, penicillin, streptomycin 24 hours later and an equal volume of B cell-conditioned medium was added with $\left[{ }^{3} \mathrm{H}\right]$-thymidine to measure proliferation or with $\left[{ }^{3} \mathrm{H}\right]$-proline to measure collagen synthesis. After 18 hours, the amount of incorporated ${ }^{3} \mathrm{H}$ was quantified. Each treatment was performed in triplicate.

Flow cytometry. Fluorescence staining was performed as previously described (51). Annexin V, 7AAD, and antibodies specific for IgM, IgD, CD19, CD23, CD5, CD69, CD86, B220, MHCII, CD43, Mac-1, CD4, CD8, (BD Biosciences - Pharmingen), or CD21 (eBioscience) were used. Antibodies were conjugated to FITC, PE, allophycocyanin (APC), peridinin chlorophyll protein (PerCP), Cy-Chrome, or biotin. Biotinylated antibodies were detected with streptavidin conjugated to PerCP. Stained cells were fixed and analyzed using FACScalibur (BD Biosciences).

In vitro stimulation of CFSE-labeled B cells. To generate a stock solution, CFSE (Invitrogen Corp.) was dissolved to $5 \mathrm{mM}$ in DMSO and stored at $80^{\circ} \mathrm{C}$. Splenic B cells were MACS purified by enrichment with MACS beads coupled to the anti-B220 antibodies (Miltenyi Biotec) on the LS magnetic columns (Miltenyi Biotec) according to the manufacturer's instructions. Cells were then washed twice with RPMI 1640 , resuspended at $5 \times 10^{7}$ cells/ $\mathrm{ml}$ in a $5-\mathrm{mM}$ concentration of CSFE in warm RPMI 1640 for 10 minutes at $37^{\circ} \mathrm{C}$, washed 3 times in RPMI $1640,5 \%$ FCS, resuspended in RPMI 1640 , $5 \%$ FCS, $\beta$-mercaptoethanol, L-glutamine at $2 \times 10^{5} / 100 \mu \mathrm{l}$, and transferred into a flat-bottom 96-well plate in $100 \mu \mathrm{l} /$ well. Another $100 \mu \mathrm{l}$ RPMI was added that contained stimulating reagents at 2 times final concentration. The stimuli used were pure $\mathrm{F}\left(\mathrm{ab}^{\prime}\right)_{2}$ fragment goat anti-mouse $\operatorname{IgM}(2.5 \mu \mathrm{g} /$ $\mathrm{ml}$; Jackson ImmunoResearch Laboratories Inc.), IL-4 (25 U/ml; R\&D Systems), anti-mouse CD40 antibodies ( $0.25 \mu \mathrm{g} / \mathrm{ml}$; eBioscience), anti-RP105 antibodies (10.5 $\mu \mathrm{g} / \mathrm{ml}$; eBioscience), or LPS ( $20 \mu \mathrm{g} / \mathrm{ml}$; Sigma-Aldrich).

Immunohistochemistry. Antibodies specific for $\alpha$-SMA (clone 1A4, DakoCytomation) were used at 1:50 dilution with 30 minutes incubation. Heatinduced epitope retrieval pretreatment of tissue sections was performed in $10 \mathrm{mM}$ citrate buffer, $\mathrm{pH} 6.0$, for 30 seconds at $125^{\circ} \mathrm{C}$, kept at $90^{\circ} \mathrm{C}$ for 10 seconds, and cooled to room temperature for an additional $20 \mathrm{~min}$ utes prior to immunostaining. Binding of primary antibodies to tissue elements was detected using an MM Biotinylation Kit (Biocare Medical), with 3,3'-diaminobenzidine (DAB) substrate. Slides were counterstained with Mayer's hematoxylin for 1 minute. 
F4/80-specific antibodies (clone CI:A3-1, Serotec Inc.) were used at 20 $\mu \mathrm{g} / \mathrm{ml}$. Tissue sections were pretreated with proteinase $\mathrm{K}$ (DakoCytomation) for 5 minutes at room temperature. Binding of primary antibodies was detected using a Vector Elite ABC kit (Vector Laboratories,) using DAB substrate. Slides were counterstained with Mayer's hematoxylin for 1 minute.

TUNEL staining was performed using an ApopTag In Situ Apoptosis Detection kit (Chemicon International) according to the manufacturer's instructions. Labeled apoptotic cells were detected using DAB/nickel chloride as the substrate. Slides were counterstained for 5 minutes with methyl green (Vector Laboratories). Collagen fibers were detected using Sirius red stain (52); H\&E staining was performed as previously described (53).

$P C R$ and Ig gene rearrangement analysis. DNA was extracted from cells positively selected on $\mathrm{CD} 19^{+}$magnetic beads (Miltenyi Biotec) according to the genomic DNA isolation kit (QIAGEN) manufacturer's protocol. DNA $(2 \mu \mathrm{l}$, equivalent of about $10^{3} \mathrm{~B}$ cells) was used for amplification of the VDJ joints. Two rounds of amplification were performed using VHA, VHB, and VHE $5^{\prime}$ primers specific for J558L, Q52, and $7183 \mathrm{~V}_{\mathrm{H}}$ families; JH4E 3' primer (54) was used for the first and nested JH1 or JH4A 3' primers for the second rounds. All primers were synthesized at Biogen Idec. Twenty cycles were performed for the first round $\left(1\right.$ minute at $95^{\circ} \mathrm{C}, 1$ minute at $60^{\circ} \mathrm{C}$, and 1.5 minutes at $\left.72^{\circ} \mathrm{C}\right) ; 30$ cycles $\left(1\right.$ minute at $95^{\circ} \mathrm{C}, 1$ minute at $63^{\circ} \mathrm{C}$, and 1.5 minutes at $72^{\circ} \mathrm{C}$ ) were performed for the second round, using $2 \mu \mathrm{l}$ of the first-round reaction as a template. The expected $0.4-\mathrm{kb}$ fragment was purified from the gel and subcloned into the PCR4-TOPO vector (Invitrogen Corp.). DNA from individual colonies was prepared and sequenced using standard vector specific primers. Sequences were analyzed using the program DnaPlot (www.dnaplot.de).

Interstitial collagen quantification. A total of 3 sections from the liver (each from a different lobe) were stained for each animal. Black and white pictures of Sirius red staining were made in polarized light at $\times 50$ magnification. Pictures were made so that liver tissue occupied the whole area captured by the camera to ensure that total image area was identical in each picture
(4-10 pictures per animal). Vessels constitutively containing collagen were electronically removed from each image. Next, the amount of white staining (interstitial collagen) was quantified by MetaMorph image analysis software (Universal Imaging Corporation). Quantification is displayed in arbitrary units ( 1 correlates to 1000 pixels). The absolute amount of white area cannot be directly compared among different experiments because it varied with the intensity of Sirius red staining.

Statistics. Statistical analysis was performed using internal Microsoft Excel (Microsoft Corp.) statistical functions.

\section{Acknowledgments}

We are grateful to Klaus Rajewsky and D. Montgomery Bissell for helpful suggestions and critical reading of the manuscript. We are indebted to Scott L. Friedman, Mount Sinai School of Medicine, for the gift of the T6-HSC cell line. We would also like to thank Biogen Idec Animal Facility for excellent mouse colony maintenance and the Research Pathology laboratory for immunohistological staining and blood serum analysis; Sarah Ryan for establishing the $\mathrm{CCl}_{4}$ dosing protocol in house; Kam Cheung for TGF- $\beta$; Akos Szilvasi and Juanita Campos for maintaining the FACS facility; and Richard Tizard and the sequencing lab for sequencing DNA samples.

Received for publication February 17, 2005, and accepted in revised form August 23, 2005.

Address correspondence to: Tatiana Novobrantseva, Biogen Idec, 14 Cambridge Center, Cambridge, Massachusetts 02142, USA. Phone: (617) 914-7178; Fax: (617) 679-3148; E-mail: Tatiana.Novobrantseva@biogenidec.com.

Victor Koteliansky's present address is: Alnylam Pharmaceuticals, Cambridge, Massachusetts, USA.
1. Vicari, A.P., and Zlotnik, A. 1996. Mouse NK1.1+ $\mathrm{T}$ cells: a new family of $\mathrm{T}$ cells. Immunol. Today. 17:71-76.

2. MacDonald, H.R. 1995. NK1.1+ T cell receptoralpha/beta+ cells: new clues to their origin, specificity, and function. J. Exp. Med. 182:633-638.

3. Velardi, A., and Cooper, M.D. 1984. An immunofluorescence analysis of the ontogeny of myeloid, $\mathrm{T}$, and B lineage cells in mouse hemopoietic tissues. J. Immunol. 133:672-677.

4. Herzenberg, L.A. 2000. B-1 cells: the lineage question revisited. Immunol. Rev. 175:9-22.

5. Tiegs, G., Hentschel, J., and Wendel, A. 1992. A T celldependent experimental liver injury in mice inducible by concanavalin A. J. Clin. Invest. 90:196-203.

6. Nagy, L.E. 2003. Recent insights into the role of the innate immune system in the development of alcoholic liver disease. Exp. Biol. Med. (Maywood). 228:882-890.

7. Jungermann, K., and Katz, N. 1989. Functional specialization of different hepatocyte populations. Physiol. Rev. 69:708-764.

8. Friedman, S.L. 1999. Cytokines and fibrogenesis. Semin. Liver Dis. 19:129-140.

9. Tjandra, K., Sharkey, K.A., and Swain, M.G. 2000. Progressive development of a Th1-type hepatic cytokine profile in rats with experimental cholangitis. Hepatology. 31:280-290.

10. Cong, Y.Z., Rabin, E., and Wortis, H.H. 1991. Treatment of murine CD5- B cells with anti-Ig, but not LPS, induces surface CD5: two B-cell activation pathways. Int. Immunol. 3:467-476.

11. Crispe, I.N., Dao, T., Klugewitz, K., Mehal, W.Z., and Metz, D.P. 2000. The liver as a site of T-cell apoptosis: graveyard, or killing field? Immunol. Rev.
174:47-62.

12. Morris, D.L., and Rothstein, T.L. 1993. Abnormal transcription factor induction through the surface immunoglobulin M receptor of B-1 lymphocytes. J. Exp. Med. 177:857-861.

13. Philips, J.R., Massey, W.L., and Hunter, N. 1998. Characterization of the mitogenic response of murine CD5+ and conventional B lymphocytes to lipopolysaccharide. Immunol. Cell Biol. 76:332-342.

14. Erickson, L.D., Foy, T.M., and Waldschmidt, T.J. 2001. Murine B1 B cells require IL-5 for optimal T celldependent activation. J. Immunol. 166:1531-1539.

15. Feeney, A.J. 1990. Lack of $\mathrm{N}$ regions in fetal and neonatal mouse immunoglobulin V-D-J junctional sequences. J. Exp. Med. 172:1377-1390.

16. Gu, H., Forster, I., and Rajewsky, K. 1990. Sequence homologies, $\mathrm{N}$ sequence insertion and $\mathrm{JH}$ gene utilization in VHDJH joining: implications for the joining mechanism and the ontogenetic timing of Ly1 B cell and B-CLL progenitor generation. EMBO J. 9:2133-2140.

17. Meek, K. 1990. Analysis of junctional diversity during B lymphocyte development. Science. 250:820-823.

18. Kantor, A.B., Merrill, C.E., Herzenberg, L.A., and Hillson, J.L. 1997. An unbiased analysis of V(H)-D$\mathrm{J}(\mathrm{H})$ sequences from $\mathrm{B}-1 \mathrm{a}, \mathrm{B}-1 \mathrm{~b}$, and conventional $\mathrm{B}$ cells. J. Immunol. 158:1175-1186.

19. Kepler, T.B., Borrero, M., Rugerio, B., McCray, S.K., and Clarke, S.H. 1996. Interdependence of N nucleotide addition and recombination site choice in V(D)J rearrangement. J. Immunol. 157:4451-4457.

20. Chen, J., et al. 1993. Immunoglobulin gene rearrangement in B cell deficient mice generated by targeted deletion of the JH locus. Int. Immunol.
5:647-656

21. Hill, D.A., Jean, P.A., and Roth, R.A. 1999. Bile duct epithelial cells exposed to alpha-naphthylisothiocyanate produce a factor that causes neutrophildependent hepatocellular injury in vitro. Toxicol. Sci. 47:118-125.

22. Mackay, F., et al. 1999. Mice transgenic for BAFF develop lymphocytic disorders along with autoimmune manifestations. J. Exp. Med. 190:1697-1710.

23. Shi, Z., Wakil, A.E., and Rockey, D.C. 1997. Strainspecific differences in mouse hepatic wound healing are mediated by divergent $T$ helper cytokine responses. Proc. Natl. Acad. Sci. U. S. A. 94:10663-10668.

24. Rockey, D.C. 2000. The cell and molecular biology of hepatic fibrogenesis. Clinical and therapeutic implications. Clin. Liver Dis. 4:319-355.

25. Duffield, J.S., et al. 2005. Selective depletion of macrophages reveals distinct, opposing roles during liver injury and repair. J. Clin. Invest. 115:56-65. doi:10.1172/JCI200522675.

26. Vogel, S., et al. 2000. An immortalized rat liver stellate cell line (HSC-T6): a new cell model for the study of retinoid metabolism in vitro. J. Lipid Res. 41:882-893.

27. Casola, S., et al. 2004. B cell receptor signal strength determines B cell fate. Nat. Immunol. 5:317-327.

28. Chan, O.T., Hannum, L.G., Haberman, A.M., Madaio, M.P., and Shlomchik, M.J. 1999. A novel mouse with B cells but lacking serum antibody reveals an antibody-independent role for B cells in murine lupus. J. Exp. Med. 189:1639-1648.

29. Watanabe, H., Miyaji, C., Seki, S., and Abo, T. 1996. c-kit+ stem cells and thymocyte precursors in the livers of adult mice. J. Exp. Med. 184:687-693.

30. Taniguchi, H., Toyoshima, T., Fukao, K., and 
Nakauchi, H. 1996. Presence of hematopoietic stem cells in the adult liver. Nat. Med. 2:198-203.

31. Benedict, C.L., Gilfillan, S., Thai, T.H., and Kearney, J.F. 2000. Terminal deoxynucleotidyl transferase and repertoire development. Immunol. Rev. 175:150-157.

32. Serreze, D.V., et al. 1996. B lymphocytes are essential for the initiation of $\mathrm{T}$ cell-mediated autoimmune diabetes: analysis of a new "speed congenic" stock of NOD.Ig mu null mice. J. Exp. Med. 184:2049-2053.

33. Noorchashm, H., et al. 1997. B-cells are required for the initiation of insulitis and sialitis in nonobese diabetic mice. Diabetes. 46:941-946.

34. Chan, O., and Shlomchik, M.J. 1998. A new role for $\mathrm{B}$ cells in systemic autoimmunity: B cells promote spontaneous T cell activation in MRL-lpr/lpr mice. J. Immunol. 160:51-59.

35. Chan, O.T., Madaio, M.P., and Shlomchik, M.J. 1999. B cells are required for lupus nephritis in the polygenic, Fas-intact MRL model of systemic autoimmunity. J. Immunol. 163:3592-3596.

36. Wong, F.S., et al. 2004. Investigation of the role of B-cells in type 1 diabetes in the NOD mouse. Diabetes. 53:2581-2587.

37. Fu, Y.X., Huang, G., Wang, Y., and Chaplin, D.D. 1998. B lymphocytes induce the formation of follicular dendritic cell clusters in a lymphotoxin alphadependent fashion. J. Exp. Med. 187:1009-1018.

38. Gonzalez, M., Mackay, F., Browning, J.L., KoscoVilbois, M.H., and Noelle, R.J. 1998. The sequential role of lymphotoxin and B cells in the development of splenic follicles. J. Exp. Med. 187:997-1007.

39. Endres, R., et al. 1999. Mature follicular dendritic cell networks depend on expression of lymphotoxin beta receptor by radioresistant stromal cells and of lymphotoxin beta and tumor necrosis factor by
B cells. J. Exp. Med. 189:159-168.

40. Golovkina, T.V., Shlomchik, M., Hannum, L. and Chervonsky, A. 1999. Organogenic role of B lymphocytes in mucosal immunity. Science. 286:1965-1968.

41. Treiner, E., et al. 2003. Selection of evolutionarily conserved mucosal-associated invariant $\mathrm{T}$ cells by MR1. Nature. 422:164-169.

42. Baumgarth, N., Jager, G.C., Herman, O.C., and Herzenberg, L.A. 2000. CD4+ T cells derived from $\mathrm{B}$ cell-deficient mice inhibit the establishment of peripheral B cell pools. Proc. Natl. Acad. Sci. U. S. A. 97:4766-4771.

43. Shimamura, M., and Huang, Y.Y. 2002. Presence of a novel subset of NKT cells bearing an invariant V(alpha)19.1-J(alpha)26 TCR alpha chain. FEBS Lett. 516:97-100.

44. Godfrey, D.I., and Kronenberg, M. 2004. Going both ways: immune regulation via CD1d-dependent NKT cells. J. Clin. Invest. 114:1379-1388. doi:10.1172/JCI200423594.

45. Ikeda, A., Caldwell, R.G., Longnecker, R., and Ikeda, M. 2003. Itchy, a Nedd 4 ubiquitin ligase, downregulates latent membrane protein 2A activity in B-cell signaling. J. Virol. 77:5529-5534.

46. Portis, T., and Longnecker, R. 2003. Epstein-Barr virus LMP2A interferes with global transcription factor regulation when expressed during B-lymphocyte development. J. Virol. 77:105-114.

47. Chen, D., Liu, W., Leng, E., and Wu, B. 1998. Effect of splenectomy on CCl4-induced liver fibrosis in rats. Chin. Med. J. (Engl.). 111:779-783.

48. Ferru, I., Roye, O., Delacre, M., Auriault, C., and Wolowczuk, I. 1998. Infection of B-cell-deficient mice by the parasite Schistosoma mansoni: demonstration of the participation of B cells in granuloma modulation. Scand. J. Immunol. 48:233-240.
49. Whitfield, M.L., et al. 2003. Systemic and cell typespecific gene expression patterns in scleroderma skin. Proc. Natl. Acad. Sci. U. S. A. 100:12319-12324.

50. Kondo, K., et al. 2001. Establishment and characterization of a human B cell line from the lung tissue of a patient with scleroderma; extraordinary high level of IL- 6 secretion by stimulated fibroblasts. Cytokine. 13:220-226.

51. Forster, I., and Rajewsky, K. 1987. Expansion and functional activity of Ly-1+B cells upon transfer of peritoneal cells into allotype-congenic, newborn mice. Eur. J. Immunol. 17:521-528.

52. Luna, L.G. 1992. Histopathologic methods and color atlas of special stains and tissue artifacts. American Histolabs. Gaitheresburg, Maryland, USA. 767 pp.

53. Luna, L.G. 1968. Manual of histologic staining methods of the armed forces institute of pathology. McGraw-Hill Book Company. New York, New York, USA. 258 pp.

54. Ehlich, A., Martin, V., Muller, W., and Rajewsky, K. 1994. Analysis of the B-cell progenitor compartment at the level of single cells. Curr. Biol. 4:573-583.

55. Alt, F.W., and Baltimore, D. 1982. Joining of immunoglobulin heavy chain gene segments: implications from a chromosome with evidence of three D-JH fusions. Proc. Natl. Acad. Sci. U. S. A. 79:4118-4122.

56. Strohal, R., Helmberg, A., Kroemer, G., and Kofler, R. 1989. Mouse Vk gene classification by nucleic acid sequence similarity. Immunogenetics. 30:475-493.

57. Desiderio, S.V., et al. 1984. Insertion of $\mathrm{N}$ regions into heavy-chain genes is correlated with expression of terminal deoxytransferase in B cells. Nature. 311:752-755.

58. Lafaille, J.J., DeCloux, A., Bonneville, M., Takagaki, Y., and Tonegawa, S. 1989. Junctional sequences of $T$ cell receptor gamma delta genes: implications for gamma delta $\mathrm{T}$ cell lineages and for a novel intermediate of V-(D)-J joining. Cell. 59:859-870. 